\title{
Evaluation of formalin-fixed paraffin-embedded tissues in the proteomic analysis of parathyroid glands
}

\author{
Elena Donadio ${ }^{1 \dagger}$, Laura Giusti ${ }^{1 \dagger}$, Filomena Cetani ${ }^{2}$, Ylenia Da Valle ${ }^{1}$, Federica Ciregia ${ }^{1}$, Gino Giannaccini ${ }^{1}$, \\ Elena Pardi ${ }^{2}$, Federica Saponaro ${ }^{2}$, Liborio Torregrossa ${ }^{3}$, Fulvio Basolo ${ }^{3}$, Claudio Marcocci ${ }^{2}$ and Antonio Lucacchini ${ }^{1 *}$
}

\begin{abstract}
Background: Proteomic research in the field of parathyroid tissues is limited by the very small dimension of the glands and by the low incidence of cancer lesions (1\%). Formalin-fixed paraffin-embedded (FFPE) tissue specimens are a potentially valuable resource for discovering protein cancer biomarkers. In this study we have verified the applicability of a heat induced protein extraction from FFPE parathyroid adenoma tissues followed by a gel-based or gel-free proteomic approach in order to achieve protein separation and identification.
\end{abstract}

Results: The best results for high quality MS spectra and parameters, were obtained by using a gel-free approach, and up to 163 unique proteins were identified. Similar results were obtained by applying both SDS-out and SDSout + TCA/Acetone techniques during the gel-free method. Western blot analysis carried out with specific antibodies suggested that the antigenicity was not always preserved, while specific immunoreactions were detected for calmodulin, B box and SPRY domain-containing protein (BSPRY), peroxiredoxin 6 (PRDX 6) and parvalbumin.

Conclusions: In spite of some limitations mainly due to the extensive formalin-induced covalent cross-linking, our results essentially suggest the applicability of a proteomic approach to FFPE parathyroid specimens. From our point of view, FFPE extracts might be an alternative source, especially in the validation phase of protein biomarkers when a large cohort of samples is required and the low availability of frozen tissues might be constraining.

\section{Background}

Proteome analysis provides diagnostic information that can be essential for therapeutic predictions. Recently, we have performed a proteomic study of parathyroid glands by using a two-dimensional electrophoresis (2-DE)/mass spectrometry (MS)-based approach, and we have examined the global changes of the parathyroid adenoma tissues protein profile compared to normal parathyroid tissues [1]. This application has resulted in the identification of a panel of proteins, which are differentially expressed, and has suggested that the proteomic approach might be useful in identifying potential biomarkers in parathyroid carcinoma. Although the use of

\footnotetext{
* Correspondence: lucas@farm.unipi.it

† Contributed equally

'Department of Psychiatry, Neurobiology, Pharmacology and Biotechnology, University of Pisa, Via Bonnanno 6, Pisa, 56126, Italy

Full list of author information is available at the end of the article
}

fresh materials is desirable for any analytical technology, large cohorts of fresh-frozen human tissue samples are often difficult to acquire or might not be large enough to accurately represent the tumor origin. For example, in our experience, proteomic research studies in the field of parathyroid tumors strictly depend on the availability of parathyroid tissues (i.e. very small dimension of the glands, or low incidence of cancer lesions) both for normal and cancer samples, prompting us to find an alternative source of fresh and frozen tissues. Formalin fixed paraffin embedded (FFPE) tissues, a common tissue preservation technique, is routinely performed for the preparation of samples used for pathological analysis. The enormousness of the FFPE tissue blocks represents an invaluable and largely untapped resource for testing biomarkers and discovering new ones. For this reason, besides the use of this resource in immunohistochemistry (IHC) and in situ hybridization-based analysis,

\section{Ciomed Central}


it would be valuable to complement IHC with powerful high resolution methods and mass spectrometry-based proteomics in order to utilize this archived material as an alternative resource for research purposes. However, proteins in FFPE tissue during the fixation process undergo degradation and cross-linking, and have therefore long been thought to be unsuitable for MS-based proteomics. Only in the past few years, the identification of a few hundred or thousand proteins in FFPE tissues has been reported [2-32]. Due to protein degradation and cross-linking caused by formalin fixation, several studies have been conducted to test the applicability of other fixatives to proteomic analysis [2-26]. In these studies, proteins were extracted from ethanol-fixed [2], Fine-FIX fixed [3] and HOPE-fixed [4] paraffin embedded tissues and resolved by 2-DE. Protein profiles obtained by using these formalin-free fixatives were highly similar to those obtained by fresh-frozen tissues. Moreover, both the duration of formalin fixation [5] and tissue storage [6] have been taken into account to assess the quality of the protein extracts. In order to improve protein extraction, many protocols have been developed to extract full-length proteins [7-11] or tryptic peptides [11-14]. The quality and identity of full-length proteins have been evaluated by SDS-PAGE, Western Blot $[4,8-10]$ and 2-DE $[10,11,15]$, while tryptic peptides have been identified by LC-MS/MS $[6,11]$ or by CIEF/Nano RLPC multidimensional peptide separation [16]. In other studies, extracted proteins have been directly analyzed by MALDI-Imaging [14,17-19], and the results were comparable with those obtained by MALDI-Tof MS and nLC-MS [17]. Moreover, this strategy is suitable for FFPE tissues conserved for a long time [18]. Recently, relative and absolute protein expressions have been successfully estimated for quantitative proteomic analysis [20-26]. This proteomic application appears to be useful for biomarker discovery from FFPE tumor tissues in comparison to healthy ones [24].

In this report, we utilized an easily accessible extraction buffer coupled with a heat-induced antigen retrieval technique to obtain proteins from FFPE tissue specimens of parathyroid adenoma. The separation of proteins extracted from the FFPE tissues was performed by both gel-free and gel-based proteomics. The protein identifications were validated by western blot analysis and compared with those obtained with fresh-frozen tissues.

\section{Materials and methods \\ Materials}

Iodoacetamide (IAA), dithiothreitol (DTT), 3-[(3-Cholamidopropyl)dimethylammonio]-1-propanesulfonate (CHAPS), urea, thiourea, glycerol, sodium dodecyl sulfate (SDS), tetramethylethylenediamine (TEMED), ammonium persulfate, glycine and $30 \%$ acrylamide- $\mathrm{N}, \mathrm{N}$,
$\mathrm{N}$ bisacrylamide were acquired from Applichem (Germany). IPGs pH 3-10 NL, pharmalyte 3-10, dry strip cover fluid and the enhanced chemiluminescence (ECL) detection system were purchased from GE Health Care Europe (Uppsala, Sweden). The SDS-out precipitation kit was purchased from Thermo Scientific Rockford (IL, USA). The anti-Parvalbumin, anti-PRDX-6, anti-calmodulin, anti-MAPK1, and anti-beta actin specific primary antibodies and secondary antibodies (horseradish peroxidase (HRP)-conjugated) were from Santa Cruz Biotecnology (CA, USA). Anti-CCT-5, anti-PARK7 and antiBSPRY specific primary antibodies were from the Abnova Corporation (Taiwan). All other reagents were from standard commercial sources and were of the highest grade available.

\section{Protein extraction}

Specimens of FFPE adenoma parathyroid tissues of five patients with sporadic primary hyperparathyroidism (PHPT) were collected from the tissue bank of the pathology section of the Department of Surgery of the University of Pisa. The study was approved by the local Ethics Committee. All patients gave their informed consent for the study. Seven to fifteen $5 \mu \mathrm{m}$ section pieces obtained from each patient were pooled and deparaffinized in 2-5 changes of xylene for $10 \mathrm{~min}$ each. Then the tissues were rehydrated through a series of graded ethanol (100\% two times, $85 \%, 70 \%)$ for 10 min each. After rehydration, the tissues were resuspended in an extraction buffer of $20 \mathrm{mM}$ Tris- $\mathrm{HCl}$ at $\mathrm{pH} 4$ containing $2 \% \mathrm{SDS}$ and $0.2 \mathrm{M}$ glycine, sonicated 3 times for $10 \mathrm{sec}$ each and incubated at $4^{\circ} \mathrm{C}$ for 1 hour under agitation. The homogenates were heated at $100^{\circ} \mathrm{C}$ for $20 \mathrm{~min}$ and successively at $60^{\circ} \mathrm{C}$ for 2 hours. The crude extracts were finally clarified by centrifugation at $13000 \mathrm{~g}$ for 20 $\min$ at $4^{\circ} \mathrm{C}$. The same procedure was performed for different section pieces, only changing the $\mathrm{pH}$ values of the extraction buffer ( $\mathrm{pH} 6$ and 9). Three different extractions of pooled samples were performed at each $\mathrm{pH}$ value. The protein content of the extracts was determined by RC/DC of Biorad using albumin as the standard. For the gel-free approach, the proteins from the FFPE specimens were extracted in buffer at $\mathrm{pH} 6$ as above described. Then the protein extracts were treated to reduce the content of SDS as described below to obtain the SDS-free samples. An aliquot of these samples were lyophilized in a speed-vac (SDS-Out samples). Alternatively, an aliquot of SDS-free samples was precipitated using $10 \%(\mathrm{w} / \mathrm{v})$ TCA and $0.05 \%$ DTT. After incubation at $0^{\circ} \mathrm{C}$ for one hour, insoluble material was pelleted at $14000 \mathrm{~g}$. Pellets were washed three times with cold pure acetone and air dried (SDS-Out + TCA/ Acetone samples). The experiments were performed in triplicate. 


\section{SDS-Out precipitation kit}

In order to remove the excess SDS from the samples, the SDS-Out precipitation kit was used following the manufacture's instructions. Briefly, 1 volume of SDSOut precipitation reagent was added to 20 volumes of sample. Then the mixture was incubated in ice for 20 min and centrifuged at $10000 \mathrm{~g}$ for 10 minutes at room temperature. The supernatant was transferred to a spin cup column and centrifuged for 1 minute at $10000 \mathrm{~g}$ to clarify the supernatant. The samples were stored at $-80^{\circ}$ $\mathrm{C}$ until they were used.

\section{2-DE}

2-DE was performed using the Immobiline-polyacrylamide system as previously described [1]. For analytical gels, 150 $\mu \mathrm{g}$ of protein from each preparation was filled to $350 \mu \mathrm{l}$ with a rehydration buffer supplemented with $1 \%(\mathrm{v} / \mathrm{v})$ pharmalytes, and $\mathrm{pH}$ range from 3-10. The first dimension was run on a non-linear wide range immobilized $\mathrm{pH}$ gradient IPG ( $\mathrm{pH}$ range from $3-10,18 \mathrm{~cm}$ ), at $16^{\circ} \mathrm{C}$ on an Ettan IPGphor II apparatus (GE Health Care) according to the procedure previously described [27]. After equilibration, the strips were applied to the top 12\% SDS-PAGE gels, and electrophoresis was performed using the PROTEAN-II Multi Cell system (Bio-Rad) with constant amperage $(40 \mathrm{~mA} / \mathrm{gel})$ at $10^{\circ} \mathrm{C}$ until the front dye reached the bottom of the gel. For the preparative run, $300 \mu \mathrm{g}$ of protein from the extract, free from SDS, was loaded. Analytical gels were stained by using ammoniacal silver nitrate as previously described [28]. Alternatively, a silver stain protocol compatible with mass spectrometry analysis was performed on the preparative gels [29]. The stained gels were scanned with an Epson Expression 1680 Pro scanner, and the images were analyzed with the Image-Master 2D Platinum 6.01 (GE Health Care) software program. For the analysis, the samples were grouped into classes depending on the $\mathrm{pH}$ values. Protein spots were detected and matched among different samples. Individual spot volume values were obtained according to the program instructions. The normalized protein abundance was calculated as the spot intensity for an individual spot divided by the spot intensity for all valid spots, and then reported as a percentage of the volume.

\section{LC-ESI-MS/MS analysis}

\section{Gel samples treatment for mass spectrometry}

Fragments of the gel containing proteins of interest were washed for $30 \mathrm{~min}$ with $100 \mu \mathrm{l}$ of $50 \mathrm{mM}$ ammonium bicarbonate and $30 \% \mathrm{AcN}$. Gel pieces were then dried for 30 minutes in a Hetovac vacuum centrifuge (HETO, Allerod, Denmark). Dried pieces of gel were rehydrated for $45 \mathrm{~min}$ at $4^{\circ} \mathrm{C}$ in $5-20 \mu \mathrm{l}$ of a $50 \mathrm{mM}$ ammonium bicarbonate solution containing sequencing grade trypsin at $6.25 \mathrm{ng} / \mu \mathrm{l}$ (Promega, Madison, WI, USA). After overnight incubation at $37^{\circ} \mathrm{C}$, gel pieces were dried in a high vacuum centrifuge before being rehydrated by the addition of $20 \mu \mathrm{l}$ of $\mathrm{H}_{2} \mathrm{O}$, and finally dried again. Elution of the peptides was performed with $20 \mu$ of $1 \%$ TFA for $20 \mathrm{~min}$ at room temperature with occasional shaking. The TFA solution containing the proteins was transferred to a polypropylene tube. A second elution of the peptides was performed with $20 \mu \mathrm{l}$ of $0.1 \%$ TFA in $50 \%$ AcN for $20 \mathrm{~min}$ at room temperature with occasional shaking. The second TFA solution was pooled with the first one. The volume of the pooled extracts was reduced to $1-2 \mu \mathrm{l}$ by evaporation under vacuum. Control extractions (blanks) were performed using pieces of gels devoid of proteins.

\section{Lyophilized samples treatment for mass spectrometry}

Lyophilized samples were suspended in $100 \mathrm{ml}$ of distilled water., Thirty $\mu$ l of urea (6 M in $50 \mathrm{mM}$ ammonium bicarbonate) were added to $30 \mu \mathrm{l}$ of this solution, and the mixture was incubated at $37^{\circ} \mathrm{C}$ for $30 \mathrm{~min}$. Then, $30 \mu \mathrm{l}$ of DTT (38 $\mathrm{mM}$ in distilled water) were added to the mixture, and the reduction was carried out at $37^{\circ} \mathrm{C}$ for $1 \mathrm{~h}$. Alkylation was performed by adding $60 \mu \mathrm{l}$ of iodoacetamide (108 $\mathrm{mM}$ in $50 \mathrm{mM}$ ammonium bicarbonate) during 1 hour at room temperature in the dark. Five $\mu$ l of trypsin porcine (Sigma) solution $(50 \mathrm{ng} / \mu \mathrm{l}$ in $50 \mathrm{mM}$ ammonium bicarbonate) was added, and the digestion was proceeded overnight at $37^{\circ} \mathrm{C}$. The sample was desalted with a $\mathrm{C} 18$ microspin column (Harvard Apparatus, Holliston, MA, USA), dried, and re-dissolved in $\mathrm{H}_{2} \mathrm{O} / \mathrm{CH}_{3} \mathrm{CN} / \mathrm{FA} 94.9 / 5$ / 0.1 before LC-ESI-MS/MS analysis.

LC-ESI-MS/MS was performed on a linear trap quadrupole (LTQ) Orbitrap XL from Thermo Electron (San Jose, CA, USA) equipped with a NanoAcquity system from Waters. Peptides were trapped on a home-made 5 $\mu \mathrm{m} 200 \AA$ Magic C18 AQ (Michrom) $0.1 \times 20 \mathrm{~mm}$ precolumn and separated on a home-made $5 \mu \mathrm{m} 100 \AA$ Magic C18 AQ (Michrom) $0.75 \times 150 \mathrm{~mm}$ column with a gravity-pulled emitter. The analytical separation was run for 35 min using a gradient of $\mathrm{H}_{2} \mathrm{O} / \mathrm{FA} 99.9 \% / 0.1 \%$ (solvent A) and $\mathrm{CH}_{3} \mathrm{CN} / \mathrm{FA} 99.9 \% / 0.1 \%$ (solvent B). The gradient was run as follows: $0-13$ min $95 \% \mathrm{~A}$ and $5 \% \mathrm{~B}$, then to $65 \% \mathrm{~A}$ and $35 \% \mathrm{~B}$ at $14 \mathrm{~min}$, and $20 \% \mathrm{~A}$ and $80 \% \mathrm{~B}$ at $19 \mathrm{~min}$ at a flow rate of $220 \mathrm{~nL} / \mathrm{min}$. For the MS survey scans, the orbitrap (OT) resolution was set to 60000 , and the ion population was set to $5 \times 10^{5}$ with an $\mathrm{m} / \mathrm{z}$ window from 400 to 2000 . For protein identification, up to five precursor ions were selected for collision-induced dissociation (CID). For MS/MS in the LTQ, the ion population was set to $1 \times 10 \mathrm{e} 4$ (isolation width of $2 \mathrm{~m} / \mathrm{z}$ ), while for MS/MS detection in the OT, it was set to $2 \times 10 \mathrm{e} 5$ (isolation width of $4 \mathrm{~m} / \mathrm{z}$ ) and $1 \times$ $10 \mathrm{e} 5$ (isolation width of $2 \mathrm{~m} / \mathrm{z}$ ) for gel samples and lyophilized samples, respectively, with resolution of 7500 , first mass at $\mathrm{m} / \mathrm{z}=100$, and maximum injection time of 
$750 \mathrm{~ms}$. The normalized collision energies were set to $35 \%$ for CID.

\section{Database searching and criteria for protein identification} Peak lists were generated from raw orbitrap data using the embedded software from the instrument vendor (extract_MSN.exe). The monoisotopic masses of the selected precursor ions were corrected using an inhouse written Perl script [30]. The peak list files were searched against the SwissProt/trEMBL database (Release 15.10 of 03-Nov-2009) using Mascot (Matrix Sciences, London, UK). Human taxonomy (98529 sequences) was specified for database searching. The parent ion tolerance was set to $10 \mathrm{ppm}$. Variable amino acid modifications were oxidized methionine. Trypsin was selected as the enzyme, with one potential missed cleavage, and the normal cleavage mode was used. The mascot search was validated using Scaffold 3.00.03 (Proteome Software, Portland, OR). Only proteins matching with two different peptides with a minimum probability score of $95 \%$ were considered identified.

\section{Western blot}

Western blot analysis was essentially performed as previously described [1]. Fresh/frozen tissues of PHPT patients $(n=3)$ were obtained at surgery, immediately snap frozen in liquid nitrogen, and stored at $-80^{\circ} \mathrm{C}$ until use. Both? Aliquots of proteins $(25 \mu \mathrm{g})$ from FFPE pooled tissues extracted at $\mathrm{pH} 6$ and from fresh/frozen pooled adenoma tissues were subjected to SDS-PAGE and transferred to nitrocellulose, blocked with PBS/ tween/milk and then incubated with specific polyclonal antibodies: anti-calmodulin (dilution 1:200), anti-PARK7 (dilution 1:200), anti-MAPK-1 (dilution 1:200), and antiparvalbumin $\alpha$ (dilution 1:200); anti-CCT-5 (5 $\mathrm{gg} / \mathrm{ml})$; anti- $\beta$ actin (dilution 1:1000), anti-BSPRY (dilution 1:500) and anti-PRDX6 (dilution 1:200). Antibody reactivity was detected using HRP-conjugated anti-rabbit or anti-mouse antibodies and visualized with a chemiluminescent peroxidase substrate (ECL system).

\section{Results}

Comparing FFPE parathyroid adenoma tissues extractions at different $\mathrm{pH}$ values using 2-DE

From the numerous protocols [7-11] that obtain a high protein recovery, we chose SDS detergent and the heating of samples to favor the hydrolysis of methylene bridges, and the addition of $200 \mathrm{mM}$ glycine to serve as a formaldehyde scavenger. It is known [7] that the pH of the buffer affects proteins solubilization, so in order to establish an optimized extraction method for FFPE parathyroid adenoma samples, we tested extractions at buffer $\mathrm{pH}$ values of 4, 6 and 9. The different $\mathrm{pH}$ values changed the quality of the protein extracted ions depending on the physical properties of the proteins such as the isoelectric point. Pooled samples were processed, and yields of the proteins extracted with each extraction buffer were determined after examining the number of spots detected with 2-DE. The best results for protein amounts extracted using buffer $\mathrm{pH}$ values of 4,6 and 9 were 54.3, 61.4 and $17.2 \mu \mathrm{g} / \mathrm{slice}$, respectively. Analysis of 2 -DE gels detected $158 \pm 15,186 \pm 17$ and $68 \pm 9$ (n $=3)($ mean $\pm \mathrm{SD})$ protein spots within a non-linear $\mathrm{pH}$ range from 3 to 10 for extraction buffers having $\mathrm{pH}$ values of 4, 6 and 9, respectively. The number of spots was significantly lower than that obtained from the fresh/frozen tissues as previously described by us [1], but was comparable with that reported for other FFPE tissue extracts [11]. The best results were obtained with extraction buffers at pH 6 . Typical 2-DE gel images of FFPE parathyroid protein extracts are shown in Figures 1A, B and 1C. The gel
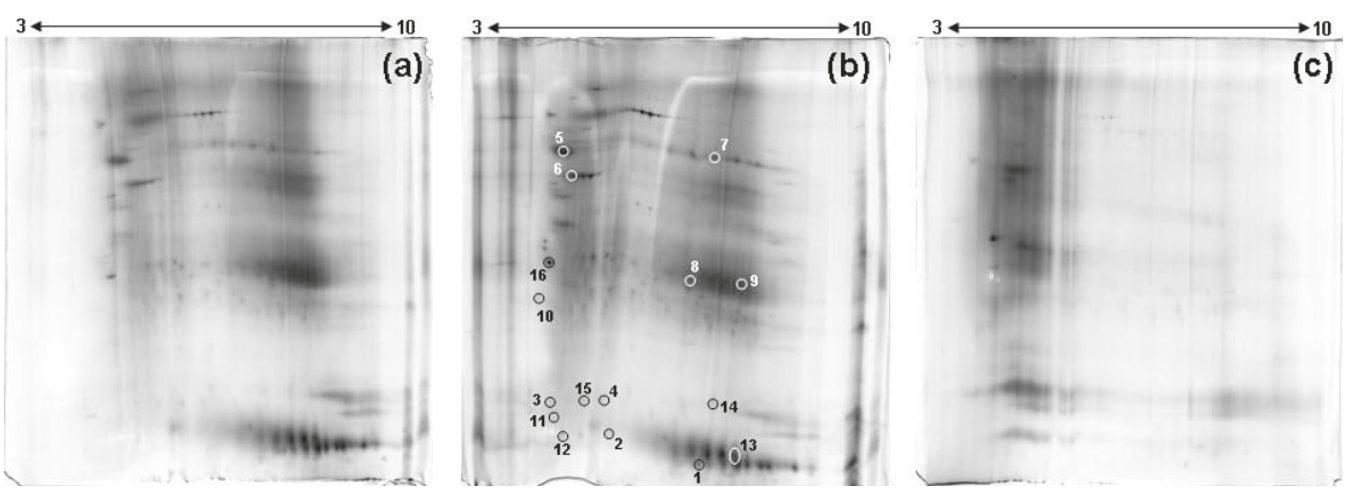

Figure 1 Representative 2-DE gel map of FFPE adenoma parathyroid tissue proteins. After deparaffinization in xylene and rehydration through a series of graded alcohols, tissue was resuspended in $20 \mathrm{mM}$ TrisHCl at pH 4 (A), 6 (B) or 9 (C) with 2\% SDS and $0.2 \mathrm{M}$ Glycine. The homogenate was heated at $100^{\circ} \mathrm{C}$ for $20 \mathrm{~min}$ and at $60^{\circ} \mathrm{C}$ for 2 hours. A total of $150 \mu \mathrm{g}$ of proteins was separated by $2-\mathrm{DE}$ using $18 \mathrm{~cm}$ pH $3-10$ NL strip and $12.5 \%$ SDS-PAGE. Proteins were detected by silver staining. The map was analyzed by Image master 2D platinum software. The gels were performed in triplicate. The reported gel images are representative of a triplicate for each pH buffer. 
replicates for $\mathrm{pH}$ values of 4, 6 and 9 showed a percentage of matched spots ranging from 85 to $95 \%$.

\section{Liquid chromatography electrospray ionization tandem mass spectrometry (LC-ESI-MS/MS) protein identifications in gel-based and in gel-free proteomic approaches Gel-Based approach}

Sixteen protein spots extracted from FFPE adenoma parathyroid tissues using buffer with $\mathrm{pH} 6$ and separated by $2 \mathrm{DE}$ were cut and analyzed by mass-spectrometry. LC-ESI-MS/MS analysis identified 37 different proteins with a $100 \%$ protein identification probability, and among these 11 identified proteins were present in multiple spots. A list of proteins identified based on estimated gel and theoretical MW and pI, number of matched peptides, best ion score, coverage percentage, and identified peptides, is shown in additional file 1. Spot No. 12 was not identified. Only Spots No. 2, No. 11 and No. 15 were identified as unique proteins, while the others led to the detection of a significant number of peptides belonging to up to nine different proteins.

\section{Gel-free approach}

The SDS-Out + TCA/Acetone and the SDS-Out protein extracts of FFPE parathyroid adenoma tissues were processed by mass spectrometry. Both samples underwent tryptic digestion and were directly analyzed by LC-ESI-MS/MS. The number of proteins identified with a protein identification probability over $95 \%$ were 95 for both SDS-Out + TCA/Acetone $(\mathrm{n}=3)$ and the SDS-Out samples $(\mathrm{n}=3)$ (additional file 2), and 28 and 40 for the separate SDS-Out + TCA/Acetone and SDS-Out samples, respectively (Tables 1 and 2). A list of identified proteins, MW, pI,best ion score, matched peptides and coverage values of the best MS/MS results are shown in Tables 1,2 and additional file 2 . The MW of the identified proteins ranged from 8 (G-protein gamma-12 subunit and ATP synthase subunit e) to $305 \mathrm{kDa}$ (thyroglobulin), while the pI ranged from 4.09 (calmodulin) to 11.36 (histone H4). The best MS/MS results were determined both from the number of peptides found for each identified protein (Figure 2A) and from the distribution of sequence coverage for the identified proteins (Figure 2B). High quality LC-ESI-MS/MS data were obtained, with more than 70 proteins that were identified with at least 2 peptides and with a sequence coverage of about of $10-20 \%$. Figures $3 \mathrm{~A}$ and $3 \mathrm{~B}$ show the pie charts of functional classification and the sub-cellular localization of all proteins identified by gel-free methodology. Table 3 shows the 17 proteins that were identified from FFPE tissues and that correspond to the proteins previously found differentially expressed in the adenoma of the fresh/frozen tissues [1].

\section{Proteins revealed by western blot}

Western blot analysis with specific antibodies was used to verify the presence of significant proteins previously identified [1] in parathyroid adenoma fresh/frozen tissues. Both FFPE and fresh/frozen tissues samples were analyzed by western blot. The representative immunoblots are shown in Figure 4. Immunoblot results showed that peroxiredoxin 6 (PRDX6), B box and SPRY domaincontaining protein (BSPRY), and parvalbumin were present in both the fresh/frozen and the FFPE tissues at the expected molecular weight (MW). In contrast, the anticalmodulin antibody detected a clear and defined signal at the expected MW $(17 \mathrm{kDa})$ in the FFPE extracts, whereas additional higher reactions $(50$ and $65 \mathrm{kDa})$ were detected in the extracts of frozen tissues. No reactions were found for mitogen activated protein kinase 1 (MAPK1), Parkinson disease protein 7 (PARK7), -T-complex protein 1 subunit epsilon (CCT-5) and $\beta$-actin.

\section{Discussion}

Recently we have shown the applicability of a proteomic approach to search for potential biomarkers in parathyroid adenomas [1], and our findings represent a promising starting point for the discovery of novel biomarkers in parathyroid carcinoma. However, some problems may occur when studying parathyroid tissues by the proteomic approach, such as the limited number of control specimens and the very low prevalence of parathyroid carcinomas (about 1\%). The availability of annotated archival tissue banks is not a resource used for biomarker research, particularly in the validation phase when large sample cohorts are required. The application of proteomic methodologies to FFPE tissues is still at the beginning stages. Many attempts were done to overcome the limits of FFPE sample preparations (i.e. protein cross-linking, protein degradation) to obtain a highthroughput extraction methodology which may be reproducible and quantitative. In the present study, protein extracts from parathyroid adenoma FFPE tissues were achieved by treatment at a high temperature, in the presence of a strong detergent and at different buffer $\mathrm{pH}$ values. Separation and identification of protein extracts were assessed by gel-based and gel-free proteomic approaches. In the gel-based methodology, the yield in terms of spot numbers resulted very low, and the best results were obtained by using a buffer extraction at $\mathrm{pH}$ 6. Based on previously published results [9-11] where 2-DE was used to analyze FFPE tissues, we confirmed the difficulty in obtaining well-resolved protein patterns, in particular for basic proteins. The MS/MS identification of the focused protein spots generated MS spectra of good quality with MS parameters comparable with those derived from proteins of fresh/frozen tissues [1]. Nonetheless, multiple identifications were found for single spots, especially in the high molecular weight and in the acidic regions, depending on an incomplete retrieval of cross-links and protein proteolysis. 
Table 1 Protein spots identified by LC-ESI-MS/MS from FFPE extracts separated by the SDS-out gel-free approach with probability over $95 \%$

\begin{tabular}{|c|c|c|c|c|c|c|}
\hline Protein name & $\begin{array}{l}\text { Accession } \\
\text { No }\end{array}$ & $\begin{array}{l}\text { Gene } \\
\text { Name }\end{array}$ & Theo & retical & $\begin{array}{l}\text { Matched } \\
\text { peptides }\end{array}$ & $\begin{array}{c}\text { Coverage } \\
(\%)\end{array}$ \\
\hline 14-3-3 protein ipsilon & P62258 & YWHAE & 29 & 4.63 & 2 & 9.4 \\
\hline 2-oxoglutarate dehydrogenase E1 component, mitochondrial & Q02218 & $\mathrm{OGDH}$ & 116 & 6.39 & 2 & 2.2 \\
\hline 3-hydroxyisobutyrate dehydrogenase, mitochondrial & P31937 & $\mathrm{HIBADH}$ & 35 & 8.38 & 2 & 7.1 \\
\hline $40 S$ ribosomal protein S5 & P46782 & RPS5 & 23 & 9.73 & 2 & 14 \\
\hline $40 S$ ribosomal protein 57 & P62081 & RPS7 & 22 & 10.09 & 2 & 18 \\
\hline 605 acidic ribosomal protein P2 & P05387 & RPLP2 & 12 & 4.42 & 2 & 24 \\
\hline ADP/ATP translocase 1 & P12235 & SLC25A4 & 33 & 9.78 & 2 & 12 \\
\hline Aspartate aminotransferase, cytoplasmic & P17174 & GOT1 & 46 & 6.53 & 2 & 9.4 \\
\hline ATP synthase subunit b, mitochondrial & P24539 & ATP5F1 & 29 & 9.37 & 2 & 7.8 \\
\hline ATP synthase subunit e, mitochondrial & P56385 & ATP5 & 8 & 9.34 & 2 & 26 \\
\hline Calcium-binding mitochondrial carrier protein Aralar1 & O75746 & SLC25A12 & 75 & 8.57 & 3 & 4.9 \\
\hline Creatine kinase B-type & P12277 & CKB & 43 & 5.34 & 3 & 10 \\
\hline Cytochrome b-c1 complex subunit Rieske-like protein 1 & P0C7P4 & UQCRFSL1 & 31 & 9.04 & 3 & 17 \\
\hline Cytochrome c oxidase subunit 4 isoform 1, mitochondrial & P13073 & COX4I1 & 20 & 9.52 & 2 & 16 \\
\hline D-3-phosphoglycerate dehydrogenase & O43175 & PHGDH & 57 & 6.29 & 3 & 6.2 \\
\hline Decorin & P07585 & PE & 40 & 8.75 & 2 & 11 \\
\hline Elongation factor 1-alpha 1 & P68104 & EEF1A1 & 50 & 9.10 & 2 & 5.2 \\
\hline Elongation factor 2 & P13639 & EEF2 & 95 & 6.41 & 2 & 2.9 \\
\hline Enoyl-CoA hydratase, mitochondrial & P30084 & ECHS1 & 31 & 8.34 & 2 & 13 \\
\hline Heterogeneous nuclear ribonucleoprotein $\mathrm{H}$ & P31943 & HNRNPH1 & 49 & 6.74 & 2 & 7.6 \\
\hline Isochorismatase domain-containing protein 2, mitochondrial & Q96AB3 & ISOC2 & 22 & 7.67 & 4 & 46 \\
\hline Keratin, type I cytoskeletal 16 & P08779 & KRT16 & 51 & 4.98 & 5 & 18 \\
\hline Keratin, type II cytoskeletal 2 epidermal & P35908 & KRT2 & 66 & 8.07 & 5 & 13 \\
\hline Keratin, type II cytoskeletal 6B & P04259 & KRT6B & 60 & 8.09 & 3 & 11 \\
\hline L-lactate dehydrogenase B chain & P07195 & LDHB & 37 & 5.71 & 3 & 10 \\
\hline Lumican & P51884 & LUM & 38 & 6.16 & 4 & 12 \\
\hline Lysosome-associated membrane glycoprotein 1 & P11279 & LAMP1 & 45 & 9.00 & 2 & 5.0 \\
\hline Malate dehydrogenase, cytoplasmic & P40925 & MDH1 & 36 & 6.91 & 2 & 8.7 \\
\hline Medium-chain specific acyl-CoA dehydrogenase, mitochondrial & P11310 & ACADM & 47 & 8.61 & 2 & 8.3 \\
\hline Mitochondrial 2-oxoglutarate/malate carrier protein & Q02978 & SLC25A11 & 34 & 9.92 & 5 & 18 \\
\hline NADH dehydrogenase [ubiquinone] 1 alpha subcomplex subunit 4 & O00483 & NDUFA4 & 9 & 9.42 & 2 & 25 \\
\hline Nucleoside diphosphate kinase & Q32Q12 & $\begin{array}{l}\text { NME1- } \\
\text { NME2 }\end{array}$ & 33 & 8.70 & 2 & 6.80 \\
\hline Peroxiredoxin-6 & P30041 & PRDX6 & 25 & 6.00 & 3 & 17 \\
\hline Proteasome activator complex subunit 1 & Q06323 & PSME1 & 29 & 5.78 & 2 & 9.2 \\
\hline Protein kinase $\mathrm{C}$ inhibitor-2 & Q8WYJ5 & & 14 & 6.50 & 3 & 41 \\
\hline Pyruvate dehydrogenase E1 subunit alpha somatic form mitochondrial & P08559 & PDHA1 & 43 & 8.35 & 3 & 7.9 \\
\hline Ras-related protein Rab-1A & P62820 & RAB1A & 23 & 5.93 & 2 & 13 \\
\hline Serotransferrin & P02787 & TF & 77 & 6.81 & 2 & 4.7 \\
\hline $\begin{array}{l}\text { Succinate dehydrogenase [ubiquinone] flavoprotein subunit, } \\
\text { mitochondrial }\end{array}$ & P31040 & SDHA & 73 & 7.06 & 2 & 6.6 \\
\hline Transitional endoplasmic reticulum ATPase & P55072 & VCP & 89 & 5.14 & 3 & 5.7 \\
\hline
\end{tabular}

Therefore, peptides from short residual protein fragments that remain linked could be released due to trypsin digestion and co-identified by MS/MS. Our study shows the applicability of the classical 2-DE methodology. However, the comparison between FFPE extract images and fresh/frozen tissues (data not shown) has suggested that this is not an optimal approach for a proteomic analysis of FFPE tissues. Alternatively, we carried out a gel-free method to analyze protein extracts. Unfortunately, SDS, even in small concentrations impairs the enzymatic digestion of proteins and is not compatible with mass spectrometry analysis. In our study, the use 
Table 2 Protein spots identified by LC-ESI-MS/MS from FFPE extracts separated by the SDS-out + TCA/Acetone gel-free approach with probability over $95 \%$

\begin{tabular}{|c|c|c|c|c|c|c|}
\hline \multirow[t]{2}{*}{ Protein name } & \multirow{2}{*}{$\begin{array}{l}\text { Accession } \\
\text { No }\end{array}$} & \multirow[t]{2}{*}{ Gene Name } & \multicolumn{2}{|c|}{ Theoretical } & \multirow{2}{*}{$\begin{array}{c}\text { Matched } \\
\text { peptides } \\
\text { SDS-Out +TCA }\end{array}$} & \multirow{2}{*}{$\begin{array}{c}\text { Coverage } \\
(\%) \\
\text { SDS-Out } \\
\text { +TCA }\end{array}$} \\
\hline & & & MW & $\mathrm{pl}$ & & \\
\hline 14-3-3 protein theta & P27348 & YWHAQ & 28 & 4.68 & 2 & 9.0 \\
\hline 14-3-3 protein zeta/delta & P63104 & YWHAZ & 28 & 4.73 & 2 & 11 \\
\hline 395 ribosomal protein L39, mitochondrial & Q9NYK5 & MRPL39 & 39 & 7.56 & 2 & 7.7 \\
\hline $60 S$ ribosomal protein L7 & P18124 & RPL7 & 29 & 1066 & 2 & 8.5 \\
\hline Adenine phosphoribosyltransferase & P07741 & APRT & 20 & 5.78 & 3 & 20 \\
\hline Adenylate kinase 2, mitochondrial & P54819 & AK2 & 26 & 7.67 & 2 & 11 \\
\hline Aflatoxin B1 aldehyde reductase member 2 & O43488 & AKR7A2 & 40 & 6.70 & 2 & 9.5 \\
\hline Cathepsin G & P08311 & CTSG & 29 & 11.19 & 2 & 11 \\
\hline cDNA FLJ61525, highly similar to Thyroglobulin & B4E153 & & 98 & 5.50 & 2 & 17 \\
\hline Fructose-bisphosphate aldolase A & P04075 & ALDOA & 39 & 8.30 & 4 & 9.9 \\
\hline Fumarate hydratase, mitochondrial & P07954 & $\mathrm{FH}$ & 55 & 8.85 & 2 & 6.3 \\
\hline Galectin-3-binding protein & Q08380 & LGALS3BP & 65 & 5.13 & 2 & 4.4 \\
\hline G-protein gamma-12 subunit & Q69YP5 & DKFZp762E193 & 8 & 9.14 & 2 & 38 \\
\hline Guanine nucleotide-binding protein subunit beta-2-like 1 & P63244 & GNB2L1 & 35 & 7.60 & 2 & 8.8 \\
\hline Heat shock protein HSP 90-alpha & P07900 & HSP90AA1 & 85 & 4.94 & 2 & 5.1 \\
\hline Ig kappa chain $\mathrm{C}$ region & P01834 & IGKC & 12 & 5.58 & 3 & 48 \\
\hline L-xylulose reductase & Q7Z4W1 & DCXR & 26 & 8.33 & 2 & 9.4 \\
\hline Macrophage-capping protein & P40121 & CAPG & 39 & 5.82 & 2 & 10 \\
\hline Mitochondrial import inner membrane translocase subunit Tim8 A & O60220 & TIMM8A & 11 & 5.08 & 2 & 23 \\
\hline NAD(P) transhydrogenase, mitochondrial & Q13423 & NNT & 114 & 8.31 & 2 & 2.5 \\
\hline $\begin{array}{l}\text { NADH dehydrogenase [ubiquinone] iron-sulfur protein 3, } \\
\text { mitochondrial }\end{array}$ & O75489 & NDUFS3 & 30 & 6.98 & 2 & 9.8 \\
\hline Poly(rC)-binding protein 1 & Q15365 & PCBP1 & 37 & 6.66 & 2 & 6.7 \\
\hline Profilin-1 & P07737 & PFN1 & 15 & 8.44 & 3 & 23 \\
\hline Puromycin-sensitive aminopeptidase & P55786 & NPEPPS & 103 & 5.49 & 2 & 2.7 \\
\hline Sideroflexin-1 & Q9H9B4 & SFXN1 & 36 & 9.22 & 2 & 17 \\
\hline Transaldolase & P37837 & TALDO1 & 38 & 6.37 & 2 & 7.1 \\
\hline Trifunctional enzyme subunit beta, mitochondrial & P55084 & $\mathrm{HADHB}$ & 51 & 9.45 & 2 & 4.6 \\
\hline Ubiquitin & P62988 & RPS27A & 9 & 6.56 & 2 & 33 \\
\hline
\end{tabular}

of the SDS-out kit used alone or combined with TCAacetone precipitation to remove possible detergent residues, has led to comparable results. The efficacy of the SDS-out treatment was confirmed from the absence of real improvements in terms of yield and quality of MSMS identification after TCA precipitation, suggesting the reliability of this kit in eliminating the anionic detergent. A high number of common proteins were identified in both preparations. The discrepancies observed could be due to several factors such as denaturation, solubility of the proteins, accessibility of tryptic sites, etc., which affected the number of identified peptides. Recently, several studies have been performed using a gel-free approach, but in the majority of cases. a large number of protein identifications have corresponded to a low number of identified peptides [11]. On the contrary, our MS data are encouraging both in the number of identified proteins and in the quality of the MS parameters. Over $70 \%$ of proteins were defined by a number of peptides $\geq 2$. Functional classification and cellular localization of all 163 identified proteins showed a homogenous distribution of extracted protein classes and of their relative abundance comparable with those previously reported for other tissues $[9,10]$. Nonetheless, the applicability of a gel-free procedure was supported by the retrieval of 14 of the 30 proteins previously found, differentially expressed in parathyroid adenoma when compared with normal tissues [1]. In this work, we have reported that 22 of the 30 deregulated proteins were clearly over-expressed compared to normal parathyroid. These recent results indicate that 10 of the 22 over-expressed proteins were detected in the gel-free FFPE tissue extracts. This is a very interesting point because it suggests the utility of these extracts as a source in confirming the presence in the parathyroid glands of potential biomarkers of parathyroid diseases. 


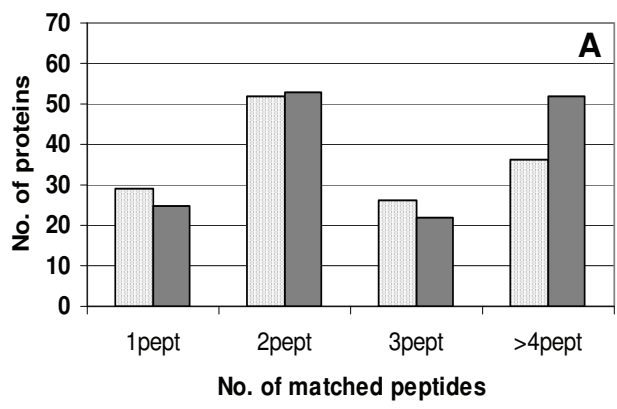

SDS-Out $\square$ sDS-Out + TCA/Acetone

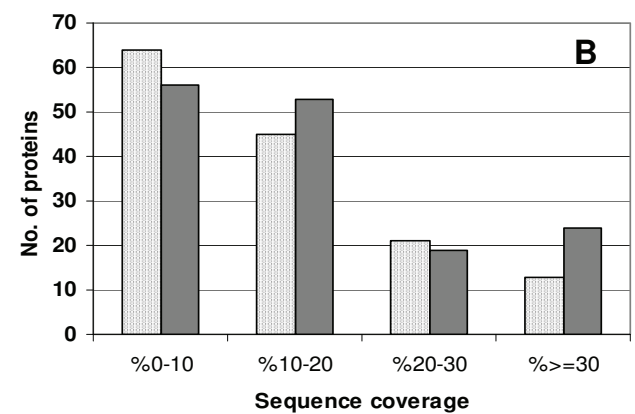

Figure 2 Gel-free approach: MS/MS sequence coverage and matched peptides. Histograms representing distribution of number of matched peptides (A) and sequence coverage (B) for proteins identified in SDS-Out and SDS-Out + TCA/Acetone sample preparations, respectively.

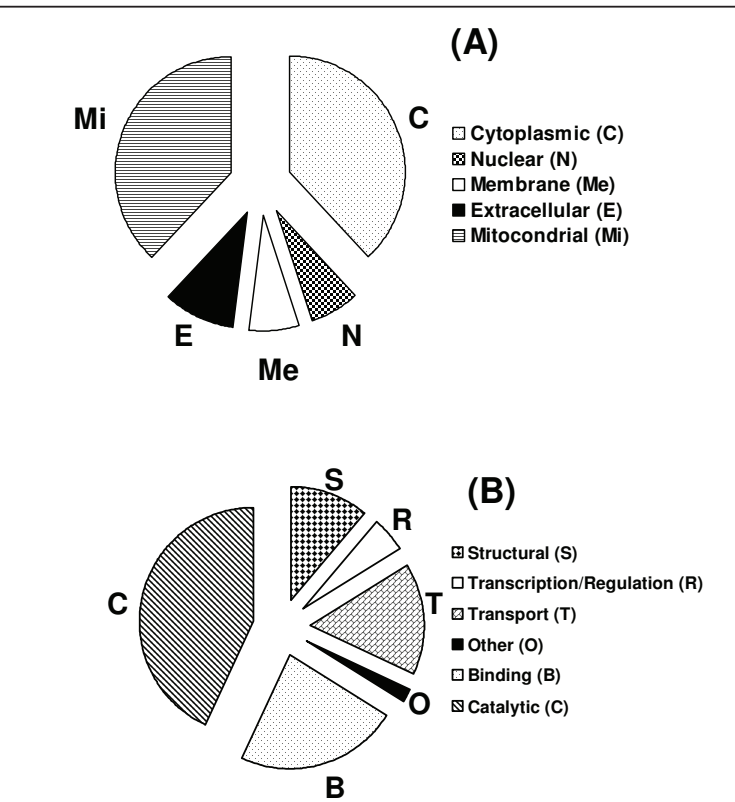

Figure 3 Subcellular localization and molecular functions Subcellular localization and molecular functions of proteins identified in FFPE adenoma tissues extracts by gel-free approaches are represented in panels $\mathbf{A}$ and $\mathbf{B}$, respectively. E, extracellular; $\mathbf{C}$, cytoplasmic; Mi, mitochondrial; N, nuclear; Me, membrane. B, binding; C, catalytic; $\mathrm{S}$, structural; $\mathrm{R}$, transcription/regulation; T, transport; $\mathrm{O}$, other.
Table 3 Proteins identified from FFPE tissues and that correspond to those differentially expressed in the adenoma of the fresh/frozen tissues

\begin{tabular}{|c|c|c|c|c|}
\hline Protein Name & $\begin{array}{l}\text { Accession } \\
\mathrm{N}^{\circ}\end{array}$ & $\begin{array}{l}\text { Theoretical } \\
\mathrm{Mr} / \mathrm{pl}\end{array}$ & $\begin{array}{l}\text { Fold } \\
\text { variation } \\
\text { adenoma } \\
\text { vs } \\
\text { normal in } \\
\text { fresh } \\
\text { frozen } \\
\text { tissue * }\end{array}$ & $\begin{array}{l}\mathrm{LC} / \mathrm{MS} / \mathrm{MS} \\
\text { from gel- } \\
\text { based (A), } \\
\text { gel-free } \\
\text { (B), or } \\
\text { both (C) }\end{array}$ \\
\hline $\begin{array}{l}\text { Voltage- } \\
\text { dependent anion } \\
\text { selective channel } \\
\text { protein1 }\end{array}$ & P21796 & $31 / 8.6$ & $\uparrow 5.1$ & B \\
\hline $\begin{array}{l}\text { Cytochrome c } \\
\text { oxidase } \\
\text { subunit5A, } \\
\text { mitochondrial }\end{array}$ & P20674 & $17 / 6.3$ & $\uparrow 7.8$ & B \\
\hline $\begin{array}{l}\text { Cytochrome b-cl } \\
\text { complex subunit } \\
1\end{array}$ & P31930 & $53 / 5.9$ & $\downarrow 2.0$ & B \\
\hline $\begin{array}{l}\text { Protein } \$ 100 \text { - } \\
\text { A11 }\end{array}$ & P31949 & $12 / 6.6$ & $\uparrow 2.9$ & A \\
\hline $\begin{array}{l}\text { Parkinson disease } \\
\text { protein } 7\end{array}$ & $\mathrm{~B} 2 \mathrm{R} 4 \mathrm{Z1}$ & $20 / 6.3$ & $\uparrow 3.4$ & B \\
\hline $\begin{array}{l}\text { Glyceraldehyde 3- } \\
\text { phosphate } \\
\text { dehydrogenase }\end{array}$ & P04406 & $36 / 8.6$ & $\uparrow 2.5$ & C \\
\hline $\begin{array}{l}\text { Apolipoprotein A- } \\
\text { I precursor }\end{array}$ & P02647 & $31 / 5.6$ & $\downarrow 1.85$ & B \\
\hline Ezrin & P15311 & $69 / 5.9$ & $\uparrow 2.3$ & B \\
\hline Parvalbumin & P20472 & $11 / 4.8$ & $\uparrow 6.1$ & A \\
\hline $\begin{array}{l}\text { Serum albumin } \\
\text { precursor }\end{array}$ & P02768 & $71 / 5.9$ & $\downarrow 1.7$ & B \\
\hline $\begin{array}{l}\text { Serotransferrin } \\
\text { precursor }\end{array}$ & P02787 & $79 / 6.8$ & $\uparrow 2.1$ & C \\
\hline $\begin{array}{l}\text { Ubiquitin carrier } \\
\text { protein } \\
\text { (Fragment) }\end{array}$ & A8MUJ2 & $16 / 5.4$ & $\uparrow 4.8$ & A \\
\hline $\begin{array}{l}40 \text { S ribosomal } \\
\text { proteín SA }\end{array}$ & P08865 & $33 / 4.8$ & $\downarrow 1.7$ & B \\
\hline Calmodulin & P62158 & $17 / 4.1$ & $\uparrow 3.2$ & B \\
\hline Annexin A5 & P08758 & $36 / 4.9$ & $\uparrow 2.7$ & B \\
\hline 14-3-3 zeta/delta & P63104 & $28 / 4.7$ & $\uparrow 2.6$ & C \\
\hline $\begin{array}{l}60 \text { kDa heat } \\
\text { shock protein, } \\
\text { mitochondrial } \\
\text { precursor }\end{array}$ & P10809 & $61 / 5.7$ & $\uparrow 4.1$ & B \\
\hline
\end{tabular}

*See reference 1

Among the proteins identified, a variety of biological functions were noted including apoptosis, electron transport, response to biotic stimulus, catabolism, lipid metabolism, cell organization, transport, protein metabolism, signal transduction and chaperon activities. Moreover, it is important to point out that proteins not identified by LC/MS/MS, probably due to their low expression, resulted detectable by western blot analysis (i.e. BSPRY). However, MAPK1, PARK7 and CCT-5 


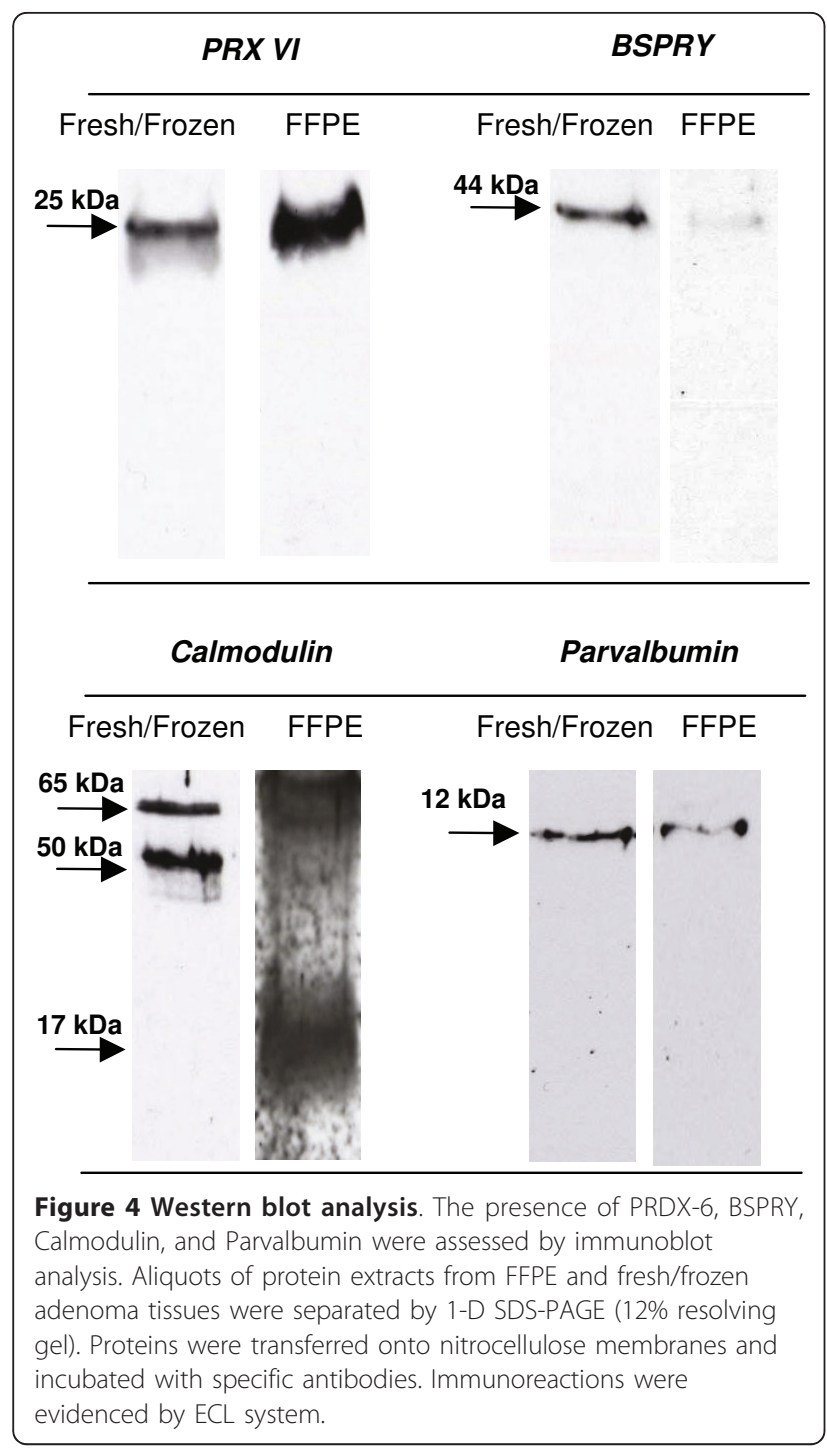

proteins were not detected in parathyroid adenoma FFPE tissue extracts using their specific antibodies. The lack of immunological detection of these proteins could be related to the alteration of antigenicity in FFPE tissues. Recently, the peculiarities in the antibodies reactivity of FFPE tissues have been investigated by Sompuram et al. [31], and in addition to western blot, other antigen-retrieval techniques (protein arrays, ELISA) were tested to detect successfully the protein reactivity in the extracts. In this respect, the choice of antibody is crucial in obtaining the best results.

\section{Conclusion}

Overall, our results are encouraging and suggest the applicability of the proteomic approach to study parathyroid FFPE tissues. In our study, the gel-free procedure gives the best results, and the use of the SDS-out kit is very efficient to remove the anionic detergent and to obtain MS-
MS high quality parameters. In addition, these results are comparable with those previously obtained with fresh/frozen parathyroid adenoma samples and demonstrate the potentiality to use these extracts as a source of protein biomarkers both in the research and in the validation phase. With this in mind, it is crucial to achieve reliable results from a quantitative point of view. As far as protein quantification, recent reports have been encouraging $[24,32]$ and indicate the feasibility to assess the differential protein expression in the archived samples and to determine that the magnitudes of differential protein expressions observed in FFPE tissue extracts are comparable to those found in the fresh/frozen samples. We think that the standardization of a method for quantitative proteomic analysis of FFPE tissues is absolutely worth pursuing, and that it could offer new opportunities in identifying-specific biomarkers and their validation using widely available archival samples. This is very important in our case, where the low-prevalence of parathyroid carcinoma is constrained by the availability of fresh/frozen tissues. In the future, we believe that the comparison between parathyroid adenoma and carcinoma FFPE tissue extracts will become realizable.

\section{Additional material}

Additional file 1: Protein spots identified by LC-ESI-MS/MS from FFPE extracts separated by the gel-based approach.

Additional file 2: Protein spots identified by LC-ESI-MS/MS from FFPE extracts separated by gel-free approaches with probability over $95 \%$

\section{Author details \\ ${ }^{1}$ Department of Psychiatry, Neurobiology, Pharmacology and Biotechnology, University of Pisa, Via Bonnanno 6, Pisa, 56126, Italy. ${ }^{2}$ Department of Endocrinology and Metabolism, Orthopedics and Traumatology, Occupational Medicine University of Pisa, Via Paradisa 2, Pisa, 56124, Italy. ${ }^{3}$ Department of Surgery, University of Pisa, Via Paradisa 2, Pisa, 56124, Italy.}

\section{Authors' contributions}

$\mathrm{AL}$ and FCe conceived of the study; ED and LG carried out the proteomic studies; FC, YDV and GG contributed to the proteomic studies; EP and FS, participated in the diagnosis; FB and LT were involved in the pathology analysis; $L G, E D, A L, C M$, FCe drafted the manuscript. All authors read and approved the final manuscript.

\section{Competing interests}

The authors declare that they have no competing interests.

Received: 17 February 2011 Accepted: 8 June 2011 Published: 8 June 2011

\section{References}

1. Giusti L, Cetani F, Ciregia F, Da Valle Y, Donadio E, Giannaccini G, Banti C, Pardi E, Saponaro F, Basolo F, Berti P, Miccoli P, Pinchera A, Marcocci C, Lucacchini A: A proteomic approach to study parathyroid glands. $\mathrm{Mol}$ Biosyst 2011, 7:687-699.

2. Ahram M, Flaig MJ, Gillespie JW, Duray PH, Linehan WM, Ornstein DK, Niu S, Zhao Y, Petricoin EF, Emmert-Buck MR: Evaluation of ethanol-fixed, 
paraffin-embedded tissues for proteomic applications. Proteomics 2003, 3:413-421.

3. Stanta G, Mucelli SP, Petrera F, Bonin S, Bussolati G: A novel fixative improves opportunities of nucleic acids and proteomic analysis in human archive's tissues. Diagn Mol Pathol 2006, 15:115-123.

4. Kähler D, Alexander C, Schultz H, Abdullah M, Branscheid D, Lindner B, Zabel P, Vollmer E, Goldmann T: Proteomics out of the archive: Twodimensional electrophoresis and mass spectrometry using HOPEfixed, paraffin-embedded tissues. J Histochem Cytochem 2010, 58:221-228.

5. Xu H, Yang L, Wang W, Shi SR, Liu C, Liu Y, Fang X, Taylor CR, Lee CS, Balgley BM: Antigen retrieval for proteomic characterization of formalinfixed and paraffin-embedded tissues. J Proteome Res 2008, 7:1098-1108.

6. Sprung RW Jr, Brock JW, Tanksley JP, Li M, Washington MK, Slebos RJ, Liebler DC: Equivalence of protein inventories obtained from formalinfixed paraffin-embedded and frozen tissue in multidimensional liquid chromatography-tandem mass spectrometry shotgun proteomic analysis. Mol Cell Proteomics 2009, 8:1988-1998.

7. Fowler CB, Cunningham RE, O'Leary TJ, Mason JT: 'Tissue surrogates' as a model for archival formalin-fixed paraffin-embedded tissues. Laboratory Investigation 2007, 87:836-846.

8. Nirmalan NJ, Harnden P, Selby PJ, Banks RE: Development and validation of a novel protein extraction methodology for quantitation of protein expression in formalin-fixed paraffin-embedded tissues using western blotting. J Pathol 2009, 217:497-506.

9. Addis MF, Tanca A, Pagnozzi D, Crobu S, Fanciulli G, Cossu-Rocca P, Uzzau S: Generation of high-quality protein extracts from formalin-fixed, paraffin-embedded tissues. Proteomics 2009, 9:3815-3823.

10. Addis MF, Tanca A, Pagnozzi D, Rocca S, Uzzau S: 2-D PAGE and MS analysis of proteins from formalin-fixed, paraffin-embedded tissues. Proteomics 2009, 9:4329-4339.

11. Azimzadeh O, Barjaktarovic Z, Aubele M, Calzada-Wack J, Sarioglu H, Atkinson MJ, Tapio S: Formalin-fixed paraffin-embedded (FFPE) proteome analysis using gel-free and gel-based proteomics. J Proteome Res 2010, 9:4710-4720.

12. Palmer-Toy DE, Krastins B, Sarracino DA, Nadol JB Jr, Merchant SN: Efficient method for the proteomic analysis of fixed and embedded tissues. J Proteome Res 2005, 4:2404-2411.

13. Prieto DA, Hood BL, Darfler MM, Guiel TG, Lucas DA, Conrads TP, Veenstra TD, Krizman DB: Liquid Tissue: proteomic profiling of formalinfixed tissues. Biotechniques 2005, Suppl: 32-5.

14. Lemaire R, Desmons A, Tabet JC, Day R, Salzet M, Fournier I: Direct analysis and MALDI imaging of formalin-fixed, paraffin-embedded tissue sections. J Proteome Res 2007, 6:1295-1305.

15. Ostasiewicz P, Zielinska DF, Mann M, Wiśniewski JR: Proteome, phosphoproteome, and N-glycoproteome are quantitatively preserved in formalin-fixed paraffin-embedded tissue and analyzable by highresolution mass spectrometry. J Proteome Res 2010, 9:3688-3700.

16. Guo T, Wang W, Rudnick PA, Song T, Li J, Zhuang Z, Weil RJ, DeVoe DL, Lee CS, Balgley BM: Proteome analysis of microdissected formalin-fixed and paraffin-embedded tissue specimens. J Histochem Cytochem 2007, 55:763-772.

17. Ronci M, Bonanno E, Colantoni A, Pieroni L, Di llio C, Spagnoli LG, Federici G, Urbani A: Protein unlocking procedures of formalin-fixed paraffin-embedded tissues: application to MALDI-TOF imaging MS investigations. Proteomics 2008, 8:3702-3714.

18. Stauber J, MacAleese L, Franck J, Claude E, Snel M, Kaletas BK, Wiel IM, Wisztorski M, Fournier I, Heeren RM: On-tissue protein identification and imaging by MALDI-ion mobility mass spectrometry. J Am Soc Mass Spectrom 2010, 21:338-347.

19. Morita Y, Ikegami K, Goto-Inoue N, Hayasaka T, Zaima N, Tanaka H, Uehara T, Setoguchi T, Sakaguchi T, Igarashi H, Sugimura H, Setou M, Konno $\mathrm{H}$ : Imaging mass spectrometry of gastric carcinoma in formalinfixed paraffin-embedded tissue microarray. Cancer Sci 2010, 101:267-273.

20. Negishi A, Masuda M, Ono M, Honda K, Shitashige M, Satow R, Sakuma T, Kuwabara H, Nakanishi Y, Kanai Y, Omura K, Hirohashi S, Yamada T: Quantitative proteomics using formalin-fixed paraffin-embedded tissues of oral squamous cell carcinoma. Cancer Sci 2009, 100:1605-1611.

21. Kawamura T, Nomura M, Tojo H, Fujii K, Hamasaki H, Mikami S, Bando Y, Kato H, Nishimura T: Proteomic analysis of laser-microdissected paraffin- embedded tissues: (1) Stage-related protein candidates upon nonmetastatic lung adenocarcinoma. J Proteomics 2010, 73:1089-1099.

22. Xiao Z, Li G, Chen Y, Li M, Peng F, Li C, Li F, Yu Y, Ouyang Y, Xiao Z, Chen $Z$ : Quantitative proteomic analysis of formalin-fixed and paraffinembedded nasopharyngeal carcinoma using iTRAQ labeling, twodimensional liquid chromatography, and tandem mass spectrometry. J Histochem Cytochem 2010, 58:517-527.

23. DeSouza LV, Krakovska O, Darfler MM, Krizman DB, Romaschin AD, Colgan TJ, Siu KW: mTRAQ-based quantification of potential endometrial carcinoma biomarkers from archived formalin-fixed paraffin-embedded tissues. Proteomics 2010, 10:3108-3116.

24. Tanca A, Addis MF, Pagnozzi D, Cossu-Rocca P, Tonelli R, Falchi G, Eccher A, Roggio T, Fanciulli G, Uzzau S: Proteomic analysis of formalin-fixed, paraffin-embedded lung neuroendocrine tumor samples from hospital archives. J Proteomics 2011, 74:359-370.

25. Berg D, Hipp S, Malinowsky K, Böllner C, Becker KF: Molecular profiling of signalling pathways in formalin-fixed and paraffin-embedded cancer tissues. Eur J Cancer 2010, 46:47-55.

26. Hwang SI, Thumar J, Lundgren DH, Rezaul K, Mayya V, Wu L, Eng J, Wright ME, Han DK: Direct cancer tissue proteomics: a method to identify candidate cancer biomarkers from formalin-fixed paraffinembedded archival tissues. Oncogene 2007, 26:65-76.

27. Giusti L, Baldini C, Bazzichi L, Ciregia F, Tonazzini I, Mascia G, Giannaccini G, Bombardieri S, Lucacchini A: Proteome analysis of whole saliva: a new tool for rheumatic diseases-the example of Sjögren's syndrome. Proteomics 2007, 7:1634-1643.

28. Hochstrasser DF, Patchornik A, Merril CR: Development of polyacrylamide gels that improve the separation of proteins and their detection by silver staining. Anal Biochem 1988, 173:412-423.

29. Yan JX, Wait R, Berkelman T, Harry RA, Westbrook JA, Wheeler CH, Dunn MJ: A modified silver staining protocol for visualization of proteins compatible with matrix-assisted laser desorption/ionization and electrospray ionization-mass spectrometry. Electrophoresis 2000, 21:3666-3672.

30. Scherl A, Tsai YS, Shaffer SA, Goodlett DR: Increasing information from shotgun proteomic data by accounting for misassigned precursor ion masses. Proteomics 2008, 8:2791-2797.

31. Sompuram SR, Vani K, Hafer LJ, Bogen SA: Antibodies immunoreactive with formalin fixed tissue antigens recognize linear protein epitopes. Am J Clin Pathol 2006, 125:82-90.

32. Nirmalan NJ, Hughes C, Peng J, McKenna T, Langridge J, Cairns DA, Harnden P, Selby PJ, Banks RE: Initial Development and Validation of a Novel Extraction Method for Quantitative Mining of the Formalin-Fixed, Paraffin-Embedded Tissue Proteome for Biomarker Investigations. J Proteome Res 2011, 10:896-906.

doi:10.1186/1477-5956-9-29

Cite this article as: Donadio et al.: Evaluation of formalin-fixed paraffinembedded tissues in the proteomic analysis of parathyroid glands. Proteome Science 2011 9:29.

\section{Submit your next manuscript to BioMed Central and take full advantage of:}

- Convenient online submission

- Thorough peer review

- No space constraints or color figure charges

- Immediate publication on acceptance

- Inclusion in PubMed, CAS, Scopus and Google Scholar

- Research which is freely available for redistribution

Submit your manuscript at www.biomedcentral.com/submit
C Biomed Central 